Article

\title{
Numerical Study of Remote Sensed Dredging Impacts on the Suspended Sediment Transport in China's Largest Freshwater Lake
}

\author{
Jianzhong Lu *, Haijun Li, Xiaoling Chen and Dong Liang \\ State Key Laboratory of Information Engineering in Surveying, Mapping and Remote Sensing, \\ Wuhan University, Wuhan 430079, China; lihaijun@whu.edu.cn (H.L.); xiaoling_chen@whu.edu.cn (X.C.); \\ liangdong@whu.edu.cn (D.L.) \\ * Correspondence: lujzhong@whu.edu.cn; Tel.: +86-27-6877-8755
}

Received: 30 October 2019; Accepted: 19 November 2019; Published: 21 November 2019

\begin{abstract}
As the largest freshwater lake in China, Poyang Lake plays an important role in the ecosystem of the Yangtze River watershed. The high suspended sediment concentration (SSC) has been an increasingly significant problem under the influence of extensive sand dredging. In this study, a hydrodynamic model integrated with the two-dimensional sediment transport model was built for Poyang Lake, considering sand dredging activities detected from satellite images. The sediment transport model was set with point sources of sand dredging, and fully calibrated and validated by observed hydrological data and remote sensing results. Simulations under different dredging intensities were implemented to investigate the impacts of the spatiotemporal variation of the SSC. The results indicated that areas significantly affected by sand dredging were located in the north of the lake and along the waterway, with a total affected area of about $730 \mathrm{~km}^{2}$, and this was one of the main factors causing high turbidity in the northern part of the lake. The SSC in the northern area increased, showing a spatial pattern in which the SSC varied from high to low from south to north along the main channel, which indicated close agreement with the results captured by remote sensing. In summary, this study quantified the influence of human induced activities on sediment transport for the lake aquatic ecosystem, which could help us to better understand the water quality and manage water resources.
\end{abstract}

Keywords: hydrodynamic model; remote sensing; sand dredging; suspended sediment concentration (SSC); spatiotemporal analysis; Poyang Lake

\section{Introduction}

As one of the most important factors of water environment variations, suspended sediment carries a large amount of pollutants, including nutrients and heavy metals, affecting the water turbidity, bottom elevation evolution and hydrodynamic process in the long term. The numerical model has been widely used to study the suspended sediment transport process, calibrating and validating the physical parameters, and analyzing the relationships between sediment transport, erosion, and sedimentation [1-7]. Human activities like sand dredging in the navigation channel and harbor, building artificial islands by dredger, and lifting sediment into water in the coastal zones have great impacts on the suspended sediment concentration (SSC) in an aquatic ecosystem [8]. These processes and influences can be described with the help of the numerical model [9-11]. At the same time, remote sensing technology, along with in-situ observations, has been widely applied to understand the spatial distribution of suspended sediment and monitor the dredging effects on the SSC at the spatial scale [12-16]. Considering that the numerical model is able to simulate the water flow and 
sediment transport in any spatial and temporal resolution, and reveal the physical mechanism when remote sensing is applied to monitor water and sediment at a low cost and at a large-scale, it is of great significance to combine the numerical model and remote sensing to study water flow and sediment transport scientifically [17-21].

Poyang Lake, the largest freshwater lake in China, plays an important role in the local ecosystem and has received widespread attention. Nevertheless, the inundated area of the lake has shrunk sharply, and drought has occurred quite frequently in recent years [22]. There are many reasons for this, including economic development, human activities, and climate change. The SSC has been increased significantly and the water quality has severely deteriorated under the influence of extensive sand dredging, which is having a serious impact on the natural environment, and on living and production around the lake [7,23-26]. The distribution pattern and spatial-temporal variations of SSC in the surface waters was explored using satellite images [27-30], and the potential relationship between the SSC and number of dredging vessels could be explained the dredging impacts on the sediment budget assessments in Poyang Lake [23,31]. The Poyang Lake has suffered intensive sand dredging, while the water has been disturbed, leading to extremely high turbidity. However, the impact mechanism of sand dredging on the suspended sediment concentration in Poyang Lake has not yet been well investigated.

In this study, we aimed to understand the temporal-spatial impacts of sand dredging activities on suspended sediment transport in the Poyang Lake, and a hydrodynamic integrated suspended sediment transport model was employed. The models were used to simulate the sand dredging impact on the sediment transport process continuously, using historical meteorological and hydrological data along with bottom topological data. The simulated hydrodynamic results were validated by the observed data at hydrology gauging stations. Based on the hydrodynamic model, a two-dimensional sediment transport model of Poyang Lake was developed considering sand dredging activities detected from satellite images. Finally, contrastive scenario simulations were implemented to analyze the spatiotemporal variation characteristics of SSC under different intensities of sand dredging. The impacts of sand dredging on the spatiotemporal distribution pattern of SSC were investigated to help us understand water quality variation under intensive human induced activities.

\section{Study Area and Data}

The Poyang Lake $\left(115^{\circ} 50^{\prime} \mathrm{E}-116^{\circ} 50^{\prime} \mathrm{E}, 28^{\circ} 00^{\prime} \mathrm{N}-29^{\circ} 50^{\prime} \mathrm{N}\right)$ is an important hydrological subsystem in the middle and lower Yangtze River, located in the north of central Jiangxi Province of China. Separated by Songmenshan Island in the middle of lake, Poyang Lake is geographically divided into two parts, including the narrow north lake and broad south lake (Figure 1). The lake has a storage capacity of 27.6 billion $\mathrm{m}^{3}$ and an average water depth of $8.4 \mathrm{~m}$ [32]. As a unique inland freshwater lake, there is a high variability in the water level, and the inundation area fluctuates from less than $1000 \mathrm{~km}^{2}$ in the dry season to over $3000 \mathrm{~km}^{2}$ in the wet season [33]. 


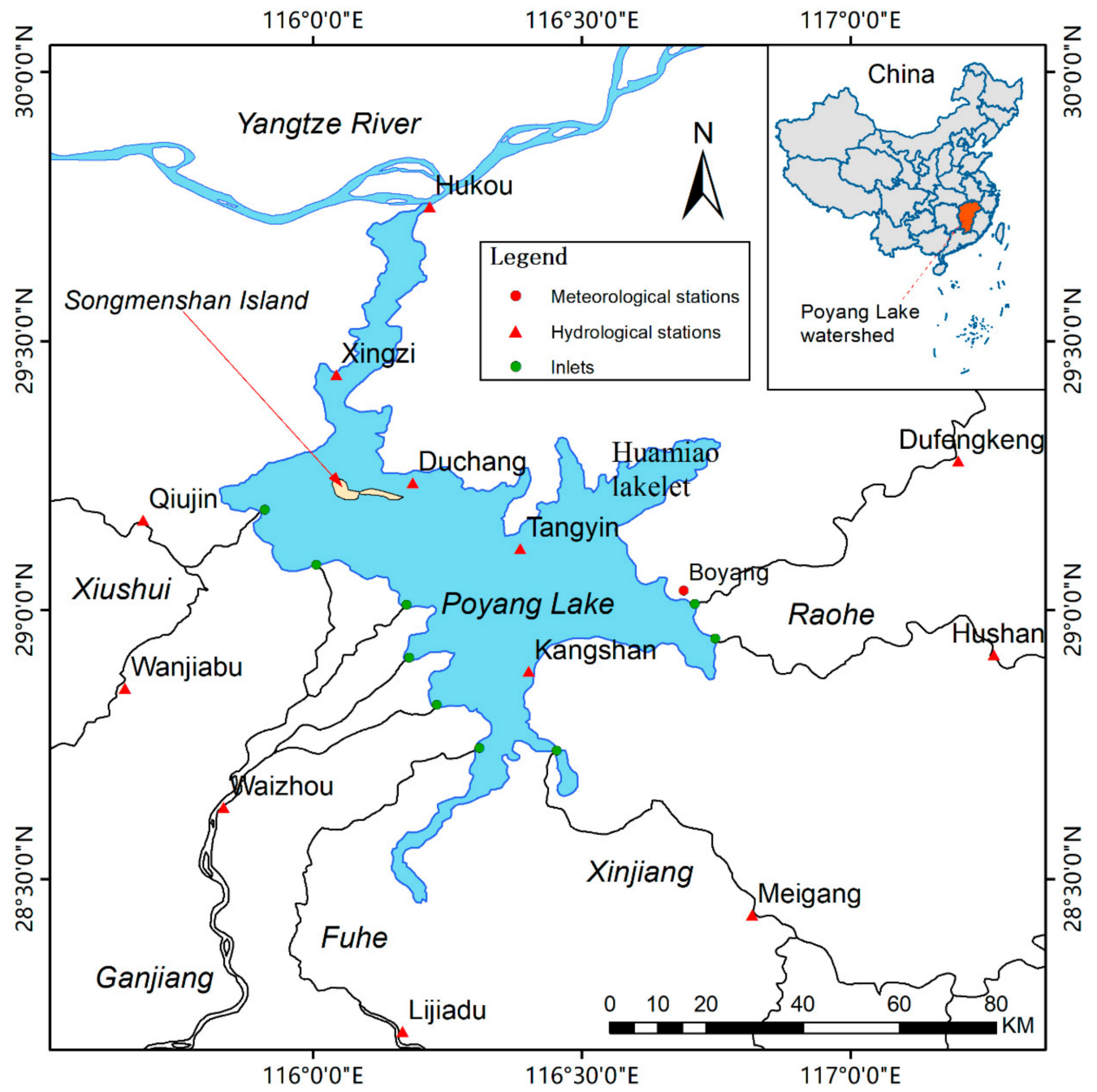

Figure 1. The location of Poyang Lake, the inflow tributaries, and the hydrological and meteorological stations. The daily river discharge and water level data during 2011 to 2015 at different hydrology gauging stations were collected from the Yangtze River Water Resources Commission and Hydrological Bureau of Jiangxi Province. The water level and water flux records were collected at Hukou station, which is located at the junction of Poyang Lake and the Yangtze River. Meteorological data at Boyang meteorological station, representing the weather that occurred over the Poyang Lake, was collected from the China Meteorological Data Sharing Service System (http://cdc.nmic.cn/). Field observations were conducted from July 15 to 23 in 2011 to measure in-situ data, including the turbidity, water depth, and suspended sediment concentration (SSC) of 50 water samples (Figure 2). Additionally, a satellite image Landsat ETM+ (Enhanced Thematic Mapper plus) was used to extract information on the sand dredging activities, in order to simulate the suspended sediment transport considering the effect of dredging activities during July 2011. 


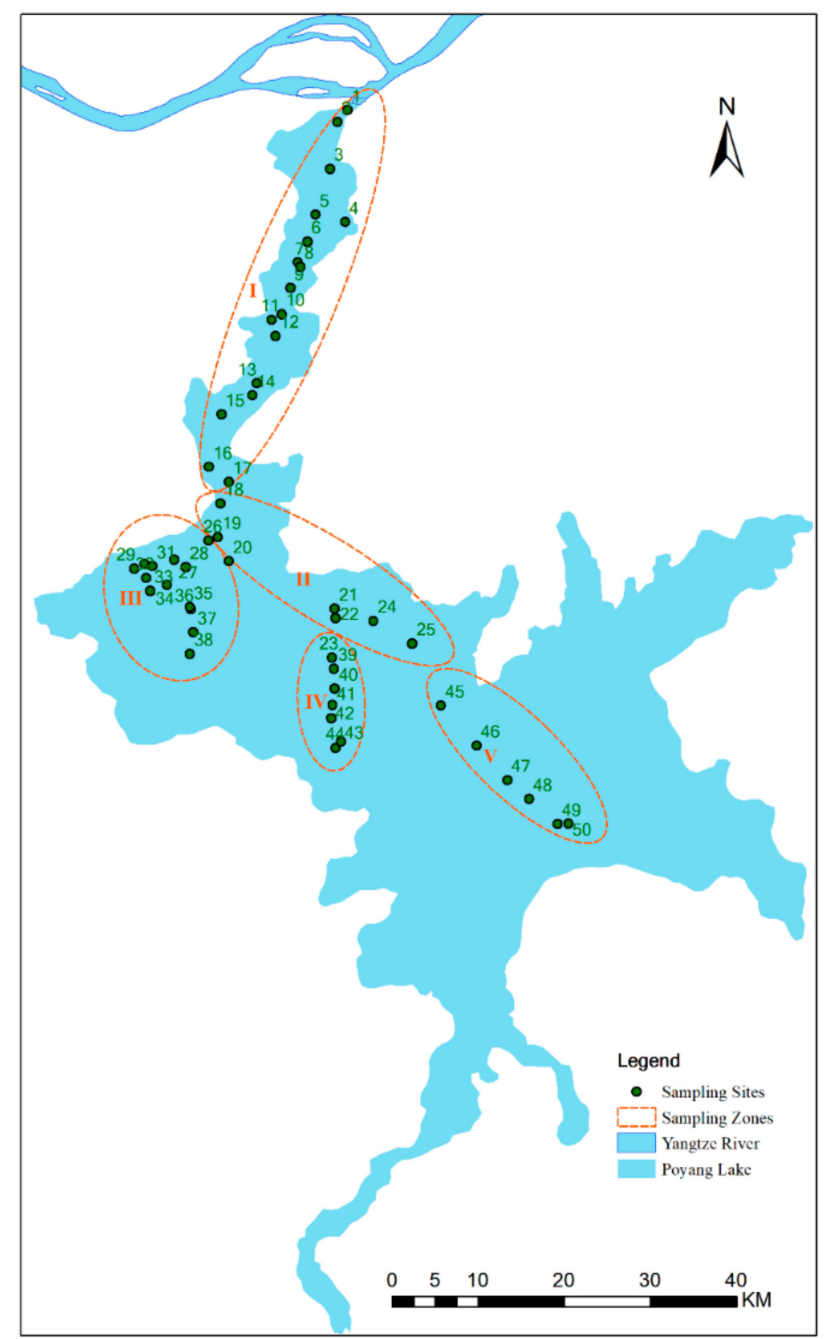

Figure 2. Spatial distribution of 50 samples in Poyang Lake during 15-23 July 2011.

As the largest freshwater lake in China, Poyang Lake has abundant water resources, with five major tributaries flowing into the lake including Xiushui River, Ganjiang River, Fuhe River, Xinjiang River, and Raohe River. The hydrological data were collected daily from the discharging rivers, including at the Qiujin, Wangjiabu, Waizhou, Lijiadu, Meigang, Hushan, and Dufengkeng hydrology gauging stations. The discharges of these rivers drain into the lake by nine main estuaries, passing through the narrow channel in the north lake and flowing into the Yangtze River. The Yangtze River has a great impact on regulating the flow from the lake, and the discharges may reverse at times from July to September, with a frequency of 708 days in 45 years [34].

Water quality has been reported to be declining in recent years in Poyang Lake. Suspended sediment is one of the major factors affecting the water quality. The mean SSC in the south lake was close to $20 \mathrm{mg} / \mathrm{L}$, and slightly higher than $20 \mathrm{mg} / \mathrm{L}$, in 2000, with a highest value greater than $60 \mathrm{mg} / \mathrm{L}$ in 2006; it was much higher in the north lake than the south lake [24]. In the most recent two decades, sand dredging has been rapidly increasing in the Poyang Lake since it was banned in the Yangtze River in 2001. Since then, sand dredging activities have been continuously carried out, though there was a ban on dredging in 2008, which has led to a significant increase in the SSC in the lake and serious negative impacts on the Poyang Lake ecosystem [33]. 


\section{Methods}

\subsection{Remote Sensing Image Processes}

Due to the heterogeneity of the high turbidity in Poyang Lake, it is difficult to efficiently detect dredging vessels by remote sensing with moderate or low resolution. In order to solve this problem, a vessel detection algorithm based on $30 \mathrm{~m}$ resolution images acquired by Landsat ETM+ (Enhanced Thematic Mapper plus) in our previous study [26] was used here to monitor the sand dredging vessels, in order to simulate the suspended sediment transport considering the effect of dredging activities during July 2011. The optimal algorithm is sufficient, with an average detection rate of $87.6 \%$ for a large lake ( $>3000 \mathrm{~km}^{2}$ in the wet season), to monitor sand dredging activities using medium resolution optical remote sensing images. The vessel detection algorithm provided an effective solution for monitoring sand dredging dynamics, as well as useful information for managing sand dredging in freshwater environments and assessing the potential impacts on aquatic ecosystems.

The temporal-spatial resolution of Moderate Resolution Imaging Spectroradiometer (MODIS) images allows monitoring of hydrology changes, the water field, and water quality at a large scale. The MODIS $250 \mathrm{~m}$ resolution daily reflectance products, MOD09GQ and MYD09GQ, were used to extract the water body and calculate the total inundated area for Poyang Lake from 2011 to 2015, to validate the hydrodynamic simulated results. Under the influence of cloud cover and sensor-induced noise, available data were limited to 196 images during 2011 to 2015 . To extract the water body precisely, a simple normalized difference vegetation index (NDVI) with the threshold method [35], aided by visual interpretation, was used. Additionally, the MODIS surface reflectance products were collected to derive the SSC distribution, to verify the model results during the simulated time using an empirical method proposed by Cui et al. [24], in which an exponential model of the MODIS Aqua red band was applied to estimate SSC from MODIS Aqua images in this study.

\subsection{Hydrodynamic-Sediment Transport Model Setup for Poyang Lake}

In this study, the Delft3D numerical modeling system developed by WL Delft Hydraulics in the Netherlands [36], which has been successfully applied in aquatic environment system simulations like hydrodynamic processes, sediment transport, and water quality, was used to set up the hydrodynamic model of Poyang Lake. This model system includes several modules, including flow, sediment, morphology, particle tracing, and orthogonal curvilinear coordinates in the horizontal direction. The Delft3D system has been developed for the modeling of unsteady water flow, temperature, salinity, and cohesive/non-cohesive sediment transport in shallows seas, estuarine and coastal areas, and rivers and lakes [37]. The Delft3D-Flow module performs hydrodynamic calculations by solving continuity and horizontal momentum equations for given initial and boundary conditions in two or three dimensions [38]. The Delft3D-Online is integrated with the Delft3D-Flow module, which enables the calculation of the fine sediment transport model by the two-dimensional advection-dispersion equation. The two dimension sediment transport can be described as Equations (1)-(3):

$$
\begin{gathered}
\mathrm{h} \frac{\partial \mathrm{c}}{\partial \mathrm{t}}+\mathrm{h} \frac{\partial \mathrm{uc}}{\partial \mathrm{x}}+\mathrm{h} \frac{\partial \mathrm{vc}}{\partial \mathrm{x}}=\frac{\partial}{\partial \mathrm{x}}\left(\mathrm{D}_{\mathrm{x}} \mathrm{h} \frac{\partial \mathrm{c}}{\partial \mathrm{t}}\right)+\frac{\partial}{\partial \mathrm{y}}\left(\mathrm{D}_{\mathrm{y}} \mathrm{h} \frac{\partial \mathrm{c}}{\partial \mathrm{y}}+\mathrm{E}-\mathrm{D}\right), \\
\mathrm{E}= \begin{cases}\mathrm{M}\left(\frac{\tau_{\mathrm{b}}}{\tau_{\mathrm{e}}}-1\right), & \tau_{\mathrm{b}}>\tau_{\mathrm{e}} \\
0, & \tau_{\mathrm{b}} \leq \tau_{\mathrm{e}}\end{cases} \\
\mathrm{D}= \begin{cases}\mathrm{w}_{\mathrm{s}} \mathrm{c}\left(1-\frac{\tau_{\mathrm{b}}}{\tau_{\mathrm{d}}}\right), & \tau_{\mathrm{b}}<\tau_{\mathrm{d}} \\
0, & \tau_{\mathrm{b}} \geq \tau_{\mathrm{d}}\end{cases}
\end{gathered}
$$

where Dx, and Dy are the diffusion coefficient in the $x$ and $y$ direction; $h$ is the water depth; $c$ is the sediment transport volume; $\mathrm{E}$ is the erosion rate; $\mathrm{D}$ is the deposition flux of suspended matter; $\mathrm{M}$ is the 
erosion rate; $\tau_{\mathrm{b}}$ is the bed stress; $\mathrm{w}_{\mathrm{s}}$ is the settling velocity of suspended matter; $\tau_{\mathrm{e}}$ is the critical shear stress for erosion; and $\tau_{\mathrm{d}}$ is the critical shear stress for deposition.

The largest area of water body was chosen to delineate the land-water boundary among the derived results with MODIS images from 2011 to 2015. The study area was divided into about 19,000 orthogonal curvilinear grids with the resolution ranging from 300 to $500 \mathrm{~m}$, and the bottom elevation was interpolated over the cells using a grid cell averaging method. The measured daily discharges of the five major incoming tributary rivers divided into nine estuaries were set as the upstream boundary conditions. Considering that Ganjiang is divided into four branches, the discharges of four estuaries were allocated by the daily measured total discharge of Waizhou station by different ratios [39]. The downstream boundary condition was set as the observed daily average water level at Hukou station. The observed water level of Duchang station, located in the middle of Poyang Lake, was set as the initial water level of the whole lake, and the initial velocity was set to zero. The time step was set to $5 \mathrm{~min}$, considering the Courant-Friedrichs-Lewy (CFL) condition and computing costs. Detailed parameter configurations can be found in our previous study [38]. Based on the flow model, the suspended sediment transport model can be applied. The observed daily sediment load of the corresponding hydrological stations of five major incoming tributary rivers were added into the upstream boundary from July 1 to 31, 2011, as well as the sediment load of four branches of Ganjiang, which were allocated by ratios that were the same as the flow model above. Except for the water level, the sediment runoff could be set as $50 \mathrm{mg} / \mathrm{L}$ and the initial suspended sediment concentration could be set as zero, referring to the previous study [40].

The sand dredging activities have been so extensive that their effects on the suspended sediment transport cannot be ignored in Poyang Lake. The Landsat ETM+ satellite images could be used to detect the location of dredging areas and dredging vessels [26]. Several sand dredging areas were recorded during field observations from July 15 to 23, 2011. Using a Landsat image on July 4, 2011, three main sand dredging areas and dredging vessels were detected (Figure 3). Area A is located in the north of Songmenshan Island, with five dredging vessels, area B is located in southeast of Songmenshan Island, with four dredging vessels, and area $C$ is located in the northwest of Tangyin, with eight dredging vessels. Considering that the SSC in the dredging center is $150 \mathrm{mg} / \mathrm{L}$ when the

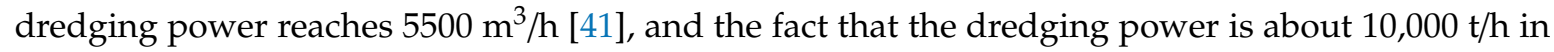
Poyang Lake and the measured SSC is $277.4 \mathrm{mg} / \mathrm{L}$ around the dredging area, the SSC in the dredging center could be set as $300 \mathrm{mg} / \mathrm{L}$ in the simulation for a single dredging vessel. As the size of a grid cell was larger than the resolution $(30 \mathrm{~m})$ of the Landsat ETM+ images, there were often several dredging vessels in the same grid cell. To simplify the model properly, a single point source of suspended sediment was configured to simulate the total effect of dredging vessels in the same grid cell and dredging area, with corresponding SSCs of 1500, 1200, and $2500 \mathrm{mg} / \mathrm{L}$ in dredging areas A, B, and C, which was consistent with the different intensities of the dredging areas in 2011 [26]. This assumed that those dredging vessels worked at the same location and had the same working hours from 8:00 to 18:00 every day during July 1 to 31, 2011. To analyze the effect of sand dredging on the SSC, another scenario was also simulated under the same conditions without dredging. 


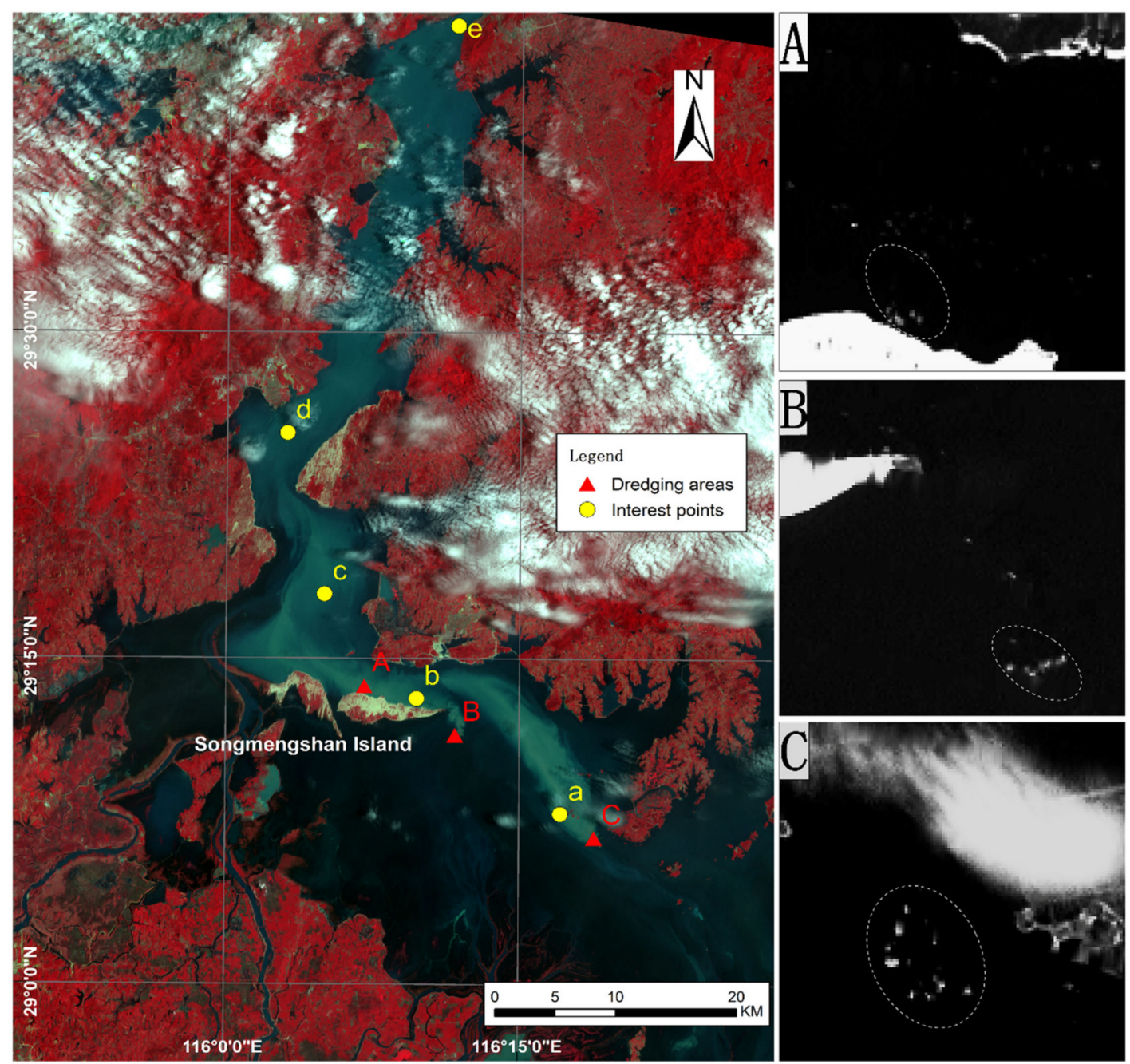

Figure 3. Three main sand dredging areas (A, B, and C in the subfigure) and five points of interest (POIs a, b , c, d, and e) in Poyang Lake on Landsat ETM+ images composed by Band 4, 3, and 2, acquired on July 4, 2011, and zoomed-in for the main dredging areas A, B, and C on Band 7, which is sensitive to dredging vessels.

\section{Results and Discussion}

\subsection{Hydrodynamic Model Validation}

The observed water levels at the Xingzi, Duchang, and Kangshan hydrology gauging stations were used to validate the simulated water level by the Poyang Lake hydrodynamic model. The simulated water levels showed close agreement with the observations at the three gauging stations (Figure 4). The coefficients of determination $\left(\mathrm{R}^{2}\right)$ of the results at Xingzi, Duchang, and Kangshan were 0.996, 0.989 , and 0.885 , respectively, and the root mean square error (RMSE) varied from 0.26 (Xingzi) to 0.63 $\mathrm{m}$ (Kangshan), while the respective error (RE) was 1.80\%, 2.12\%, and 3.35\%, indicating that the Delft3D model has the capability to catch the high-dynamic changes in water levels of Poyang Lake. The results also showed lower accuracy during the annual dry period, the reason for which may be as follows: (1) the shorelines changed from a lake into a river channel during the dry period on account of water recession, and the hydrodynamic characteristics changed a lot while the model parameter conditions remained the same as during the previous wet period, meaning the uniform model condition may result in more error during the dry period, or (2) sand dredging activities have changed the bottom bed seriously since 2001, and the bathymetric data used was measured in 2000. Consequently, the outdated bottom elevation data induced errors. 

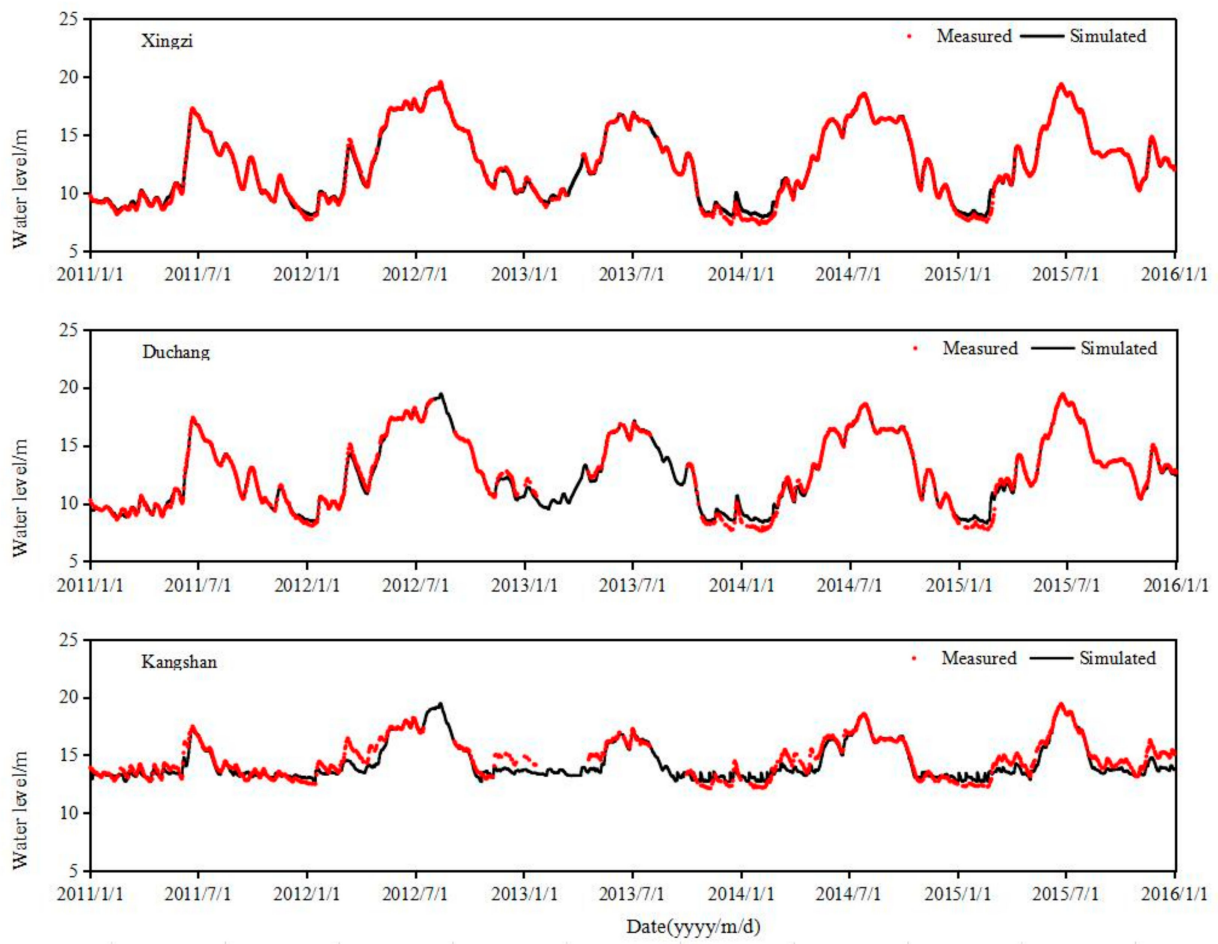

Figure 4. Comparison between model results and observations of the water level at the Xingzi, Duchang, and Kangshan gauging stations.

To explore the water exchange process between Poyang Lake and the Yangtze River, simulated discharges at the Hukou station from 2011 to 2015 were calculated (Figure 5). The simulated results were in reasonable agreement with the measured data at Hukou, with an RMSE of $1557.83 \mathrm{~m}^{3} / \mathrm{s}, \mathrm{R}^{2}$ of 0.869 , and RE of $18.70 \%$. Further, the blocking effect and flow backward phenomenon of the Yangtze River was caught during the wet periods.

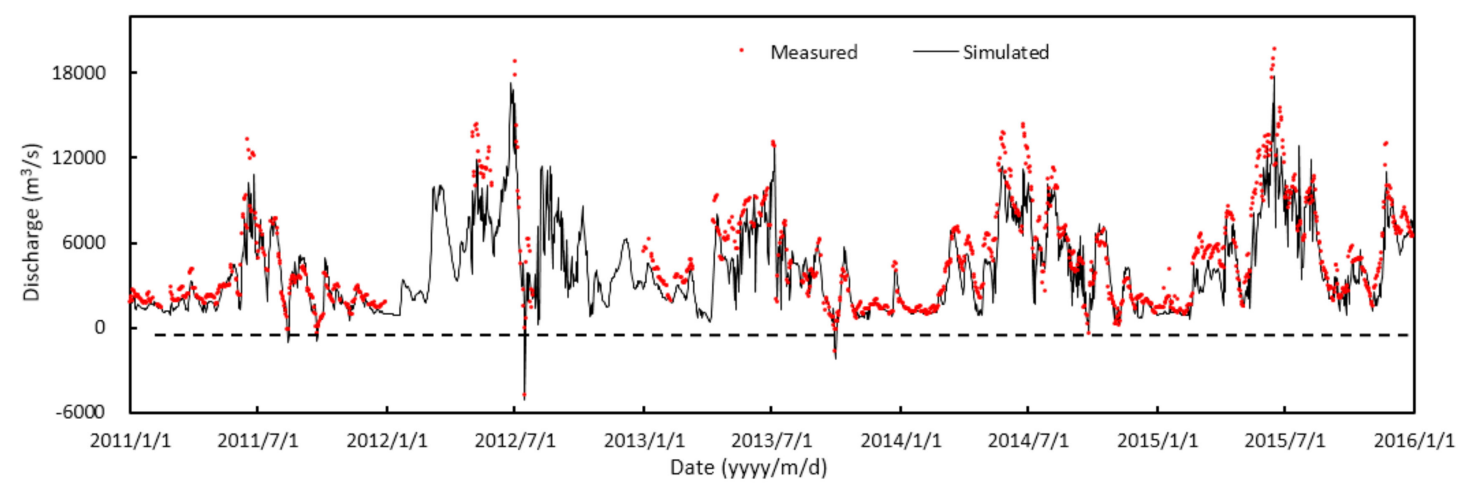

Figure 5. Comparison between model results and observations of outlet discharge at Hukou.

Based on the daily measured water level at Duchang station, located in the middle of Poyang Lake, and combined with the simulated results, the maximum and minimum inundated area, corresponding time of model and MODIS, the water level on the day, and the ratio of maximum and minimum area can be calculated. The maximum inundated area occurs in the wet period, mainly in June or July, while the minimum area occurs in the dry period from December to February. The simulated ratios of the maximum and minimum area are close to those derived from MODIS images, with the largest of 4.25, which reflects the high-dynamic changes of the water field of the lake. The result of a large inundation area change rate was similar to the findings by Feng et al. [21]. Figure 6 shows the comparison of the maximum and minimum inundated area of the model results and those derived from 
MODIS images. In general, the maximum and minimum inundated areas show similar morphology and water distribution of Poyang Lake - the shape of the lake is almost full in the wet period and a river with some lakelets scattered around occurs in the dry period-indicating the annual high-dynamic changes of the lake. In the south of Songmenshan Island, close to the estuary of Xiu River and Ganjiang River, a water body exists in the simulated results but not in the MODIS images, which may be due to the simple NDVI threshold used to extract the water field in the satellite images. The spectral characteristics in those mud areas near the estuary differ from a natural water body like the main lake, causing errors in the extraction with NDVI. In addition, there was a good consistency between the model simulated water area and the MODIS extracted results (Figure 7), with an RMSE of $283.47 \mathrm{~km}^{2}$, $\mathrm{R}^{2}$ of 0.829 , and $\mathrm{RE}$ of $15.90 \%$, suggesting that the calibrated model could be further employed in suspended sediment transport simulation.
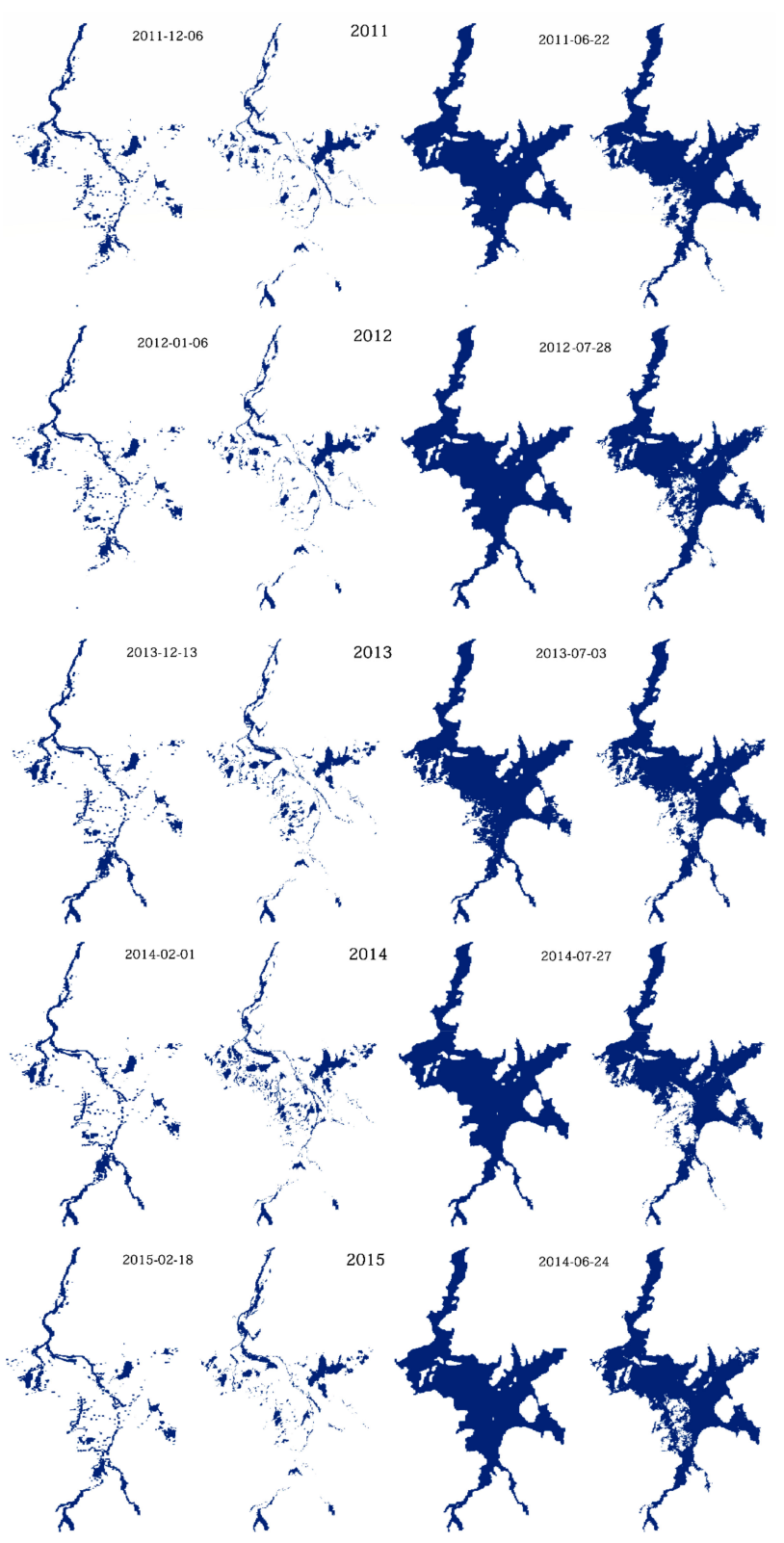

Figure 6. Comparison of the maximum and minimum inundated areas of the model results (left of the date) and those derived from Moderate Resolution Imaging Spectroradiometer (MODIS) images (right of the date). 


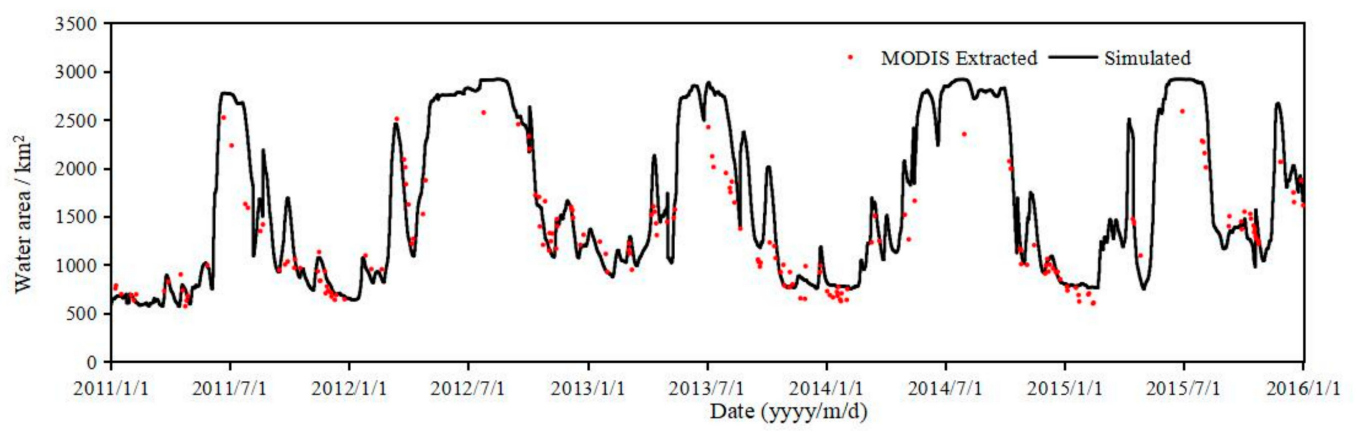

Figure 7. Comparison between MODIS extracted water areas and model simulated results.

\subsection{Simulation of Sand Dredging Effects on the Suspended Sediment Concentration}

The SSC, simulated with/without sand dredging, was also validated by 50 samples of in-situ observation during the cruises of July 15 to 23 July, 2011 (Figure 8). When sand dredging activities were ignored in the simulation, there were large deviations between the simulated results and the in-situ observed data. For some samples, like Site 18, 20, 24, and 25, the SSC values observed were higher than $100 \mathrm{mg} / \mathrm{L}$ but much lower in the model without dredging, and increased a lot to a level close to the measured values in the dredging model. After integrating the sand dredging into the model, the simulated results were improved, with an $\mathrm{R}^{2}$ of 0.831 and RMSE of $15.5 \mathrm{mg} / \mathrm{L}$, which were validated against the observed data. The results show the simulation of the SSC in Poyang Lake could be made more effective by considering sand dredging activities.

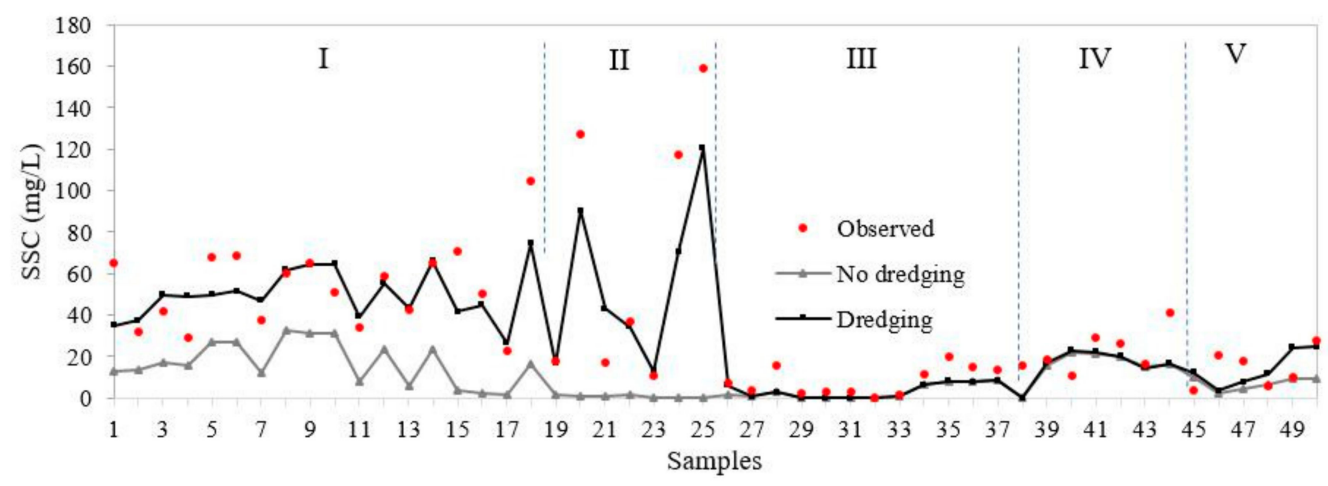

Figure 8. Comparison between the SSC, simulated with or without dredging, and in-situ observations during July 15 to 23, 2011.

Three main dredging areas showed different effects on the samples in different zones of the lake (Figure 2). Sites 1 to 17 were located in Zone I, namely the long and narrow channel in the north of the lake, where upstream suspended sediment transport affected the SSC here synthetically. Sites 18 to 25 were located in Zone II, close to the dredging areas A and B, where the SSC increased greatly under the influence of dredging. However, the SSC showed a stable trend in Zones III, IV, and V, which were located in the upstream of a dredging area or in the south main lake with the obstruction of Songmenshan Island.

Using the SSC results derived from cloud free MODIS satellite images on July 4 and 20, 2011, the SSC simulated by the suspended sediment transport model with or without sand dredging could be compared (Figure 9). In the model without dredging, the SSC of the lake was low in general, with a maximum of about $80 \mathrm{mg} / \mathrm{L}$ in the north. The spatial pattern varied from the results derived from MODIS. After sand dredging was considered, the SSC in the northern area increased, with a spatial pattern of the SSC which varied from high to low from south to north along the main channel, indicating a close agreement with the MODIS derived results. Around the center of the dredging activities, the SSC showed abnormally high values-much higher than those retrieved from remote 
sensing. The potential factors affecting this may include the following: (1) the grid size was much larger than the resolution of the Landsat images $(30 \mathrm{~m}$ ) used to detect sand dredging vessels, which meant that there were several vessels in the same grid to be simulated as a single point source of suspended sediment. Hence, the aggregation of multiple dredging vessels caused a high SSC for the center grid cell in the dredging areas, and using fine grid cells to represent multiple vessels in a cell may eliminate the abnormally high SSC in the center of dredging, or (2) the corresponding relationship and calculation of dredging power and point of SSC referenced could be closer to the Poyang Lake regionally, and improved to give more accurate simulations.

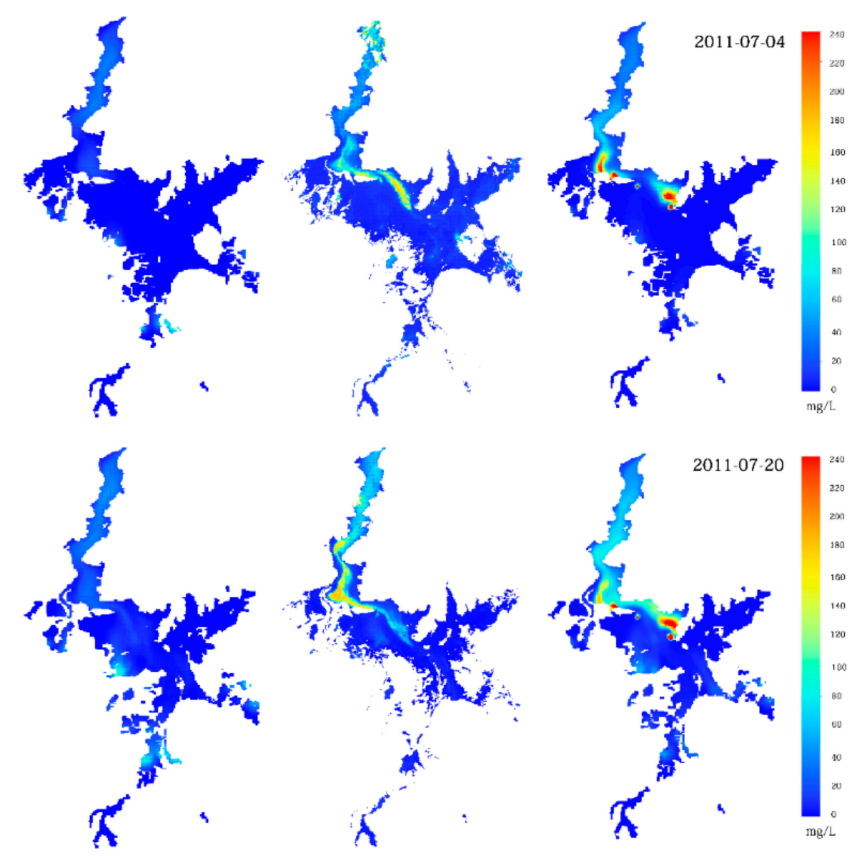

Figure 9. Comparison of the SSC spatial distribution, simulated with (left) or without (right) dredging, and MODIS derived (center) on July 4 and 20, 2011.

\subsection{Spatial and Temporal Impacts of Dredging on the Suspended Sediment in Poyang Lake}

To investigate the affected area and variation of the spatial pattern quantitatively, the maximum increment of the SSC was defined as the difference between the largest SSC in stable status with dredging and the SSC in normal status with no dredging. The spatial distribution of the maximum increment of the SSC under different dredging intensities is presented as Figure 10. Generally, the maximum increment of the SSC caused by sand dredging varied from large to small from south to north, upstream near the dredging area to downstream along the channel. Additionally, it increased relatively with dredging intensity. Specifically, the maximum of the SSC near the center of the dredging areas reached about $70 \mathrm{mg} / \mathrm{L}$ when the dredging intensity was $300 \mathrm{mg} / \mathrm{L}$ (single dredging vessel). The maximum increment of the SSC in the north of the lake increased dramatically, especially in the center of the waterway channel, with a maximum of $300 \mathrm{mg} / \mathrm{L}$ under a dredging intensity of $1500 \mathrm{mg} / \mathrm{L}$ (five dredging vessels). Although fluctuation existed in the water area of different concentrations, the total area affected under these different dredging intensities was stable to an extent across an area of $730 \mathrm{~km}^{2}$. 


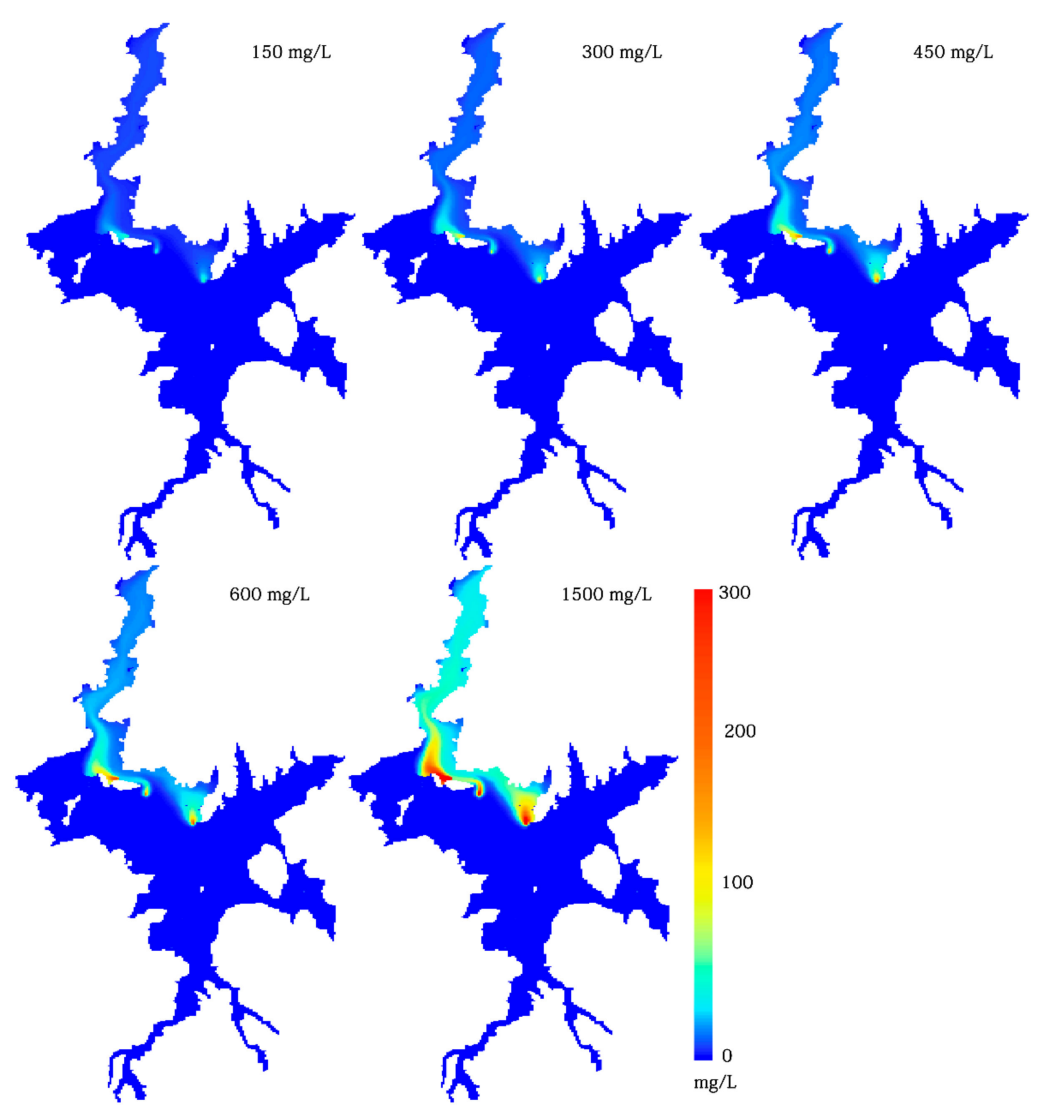

Figure 10. The spatial distribution the maximum increment of the SSC under different dredging intensities.

Considering that the suspended sediment is transported with the water flow from dredging centers to downstream in the waterway channel in the north of the lake, the sediment diffused slightly from the dredging center, causing a slight increase of the total affected area. This suggested that sand dredging in these three dredging areas showed nearly no effects in the south of the main lake and river inlets, but huge effects in the north of the lake, including the area west of Tangyin station, north of Songmenshan Island, the waterway channel, and the outlet to the Yangtze River, which was one of the main reasons for high turbidity water in the northern lake.

From south to north along the main channel, five points of interest (POIs, a, b, c, d, and e) were chosen for further exploration of the effects of dredging on the SSC. Figure 11 shows the maximum increment of the SSC and the recovery time to normal status for the five POIs under different dredging intensities. In general, there were similar SSCs for all the points when the dredging intensity was $150 \mathrm{mg} / \mathrm{L}$, but it increased gradually along with the dredging intensity, showing a spatial pattern of the maximum increment of the SSC varying from large to small from south to north along the channel. However, the recovery time to normal status of the points showed a relatively opposite trend of the maximum increment of the SSC, which varied from short to long from south to north along the channel. This suggested a positive correlation between the maximum increment of the SSC and the dredging intensity, as well as a relationship between the recovery time and the dredging intensity. The closer to the dredging area the POI was, the larger the maximum increment at the POI, and the recovery time was longer downstream than upstream. 

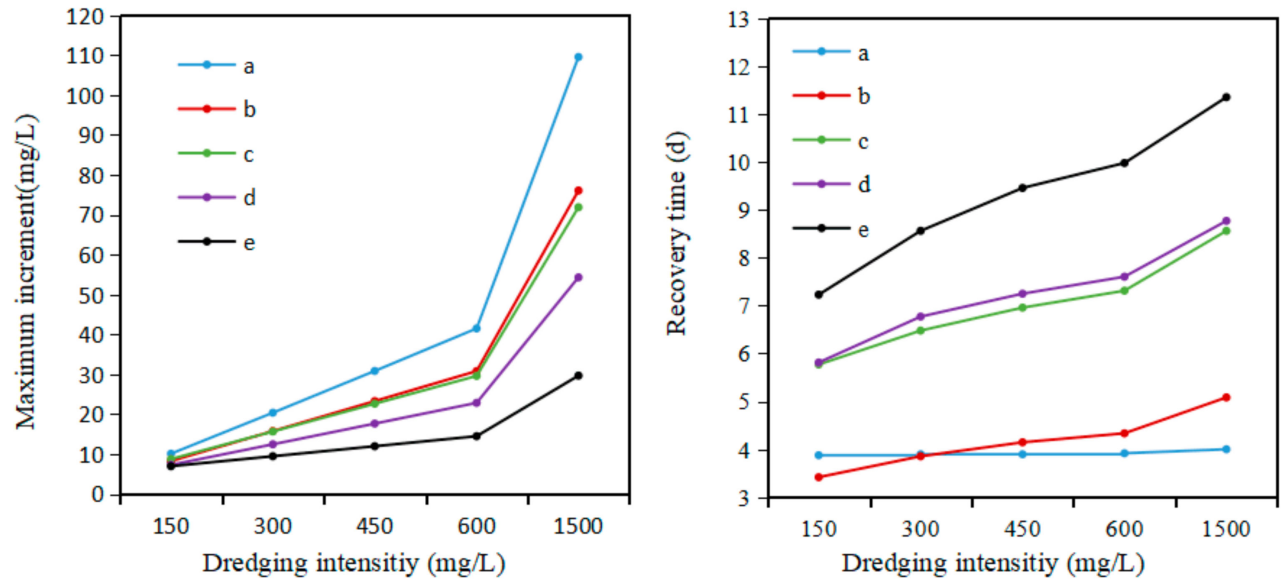

Figure 11. The maximum increment of the SSC and the recovery time to normal status for the five POIs under different dredging intensities.

Specifically, there was a similar level of SSC and trend line at the POIs b and c, but the recovery times were varied. The reasons for this may be the following: (1) the POI $b$ was close to dredging area $\mathrm{A}$ and was heavily influenced, while the POI $\mathrm{c}$ was further away from the center of the dredging area but was influenced by dredging area $A$ combined with area $B$, resulting in a similar maximum increment variation as POI b; (2) from the perspective of the velocity field simulated in the north of the lake (Figure 12), the depth averaged velocity in the narrow channel (in POI b) was much larger than in the open water area (in POI c), indicating a larger diffusion rate in this area, meaning water exchange occurred more quickly with the upstream discharge than in open water for the SSC under the influence of sand dredging activities. Therefore, the high turbidity induced by sand dredging would quickly recover to normal status in this narrow channel in the case that sand dredging stops.

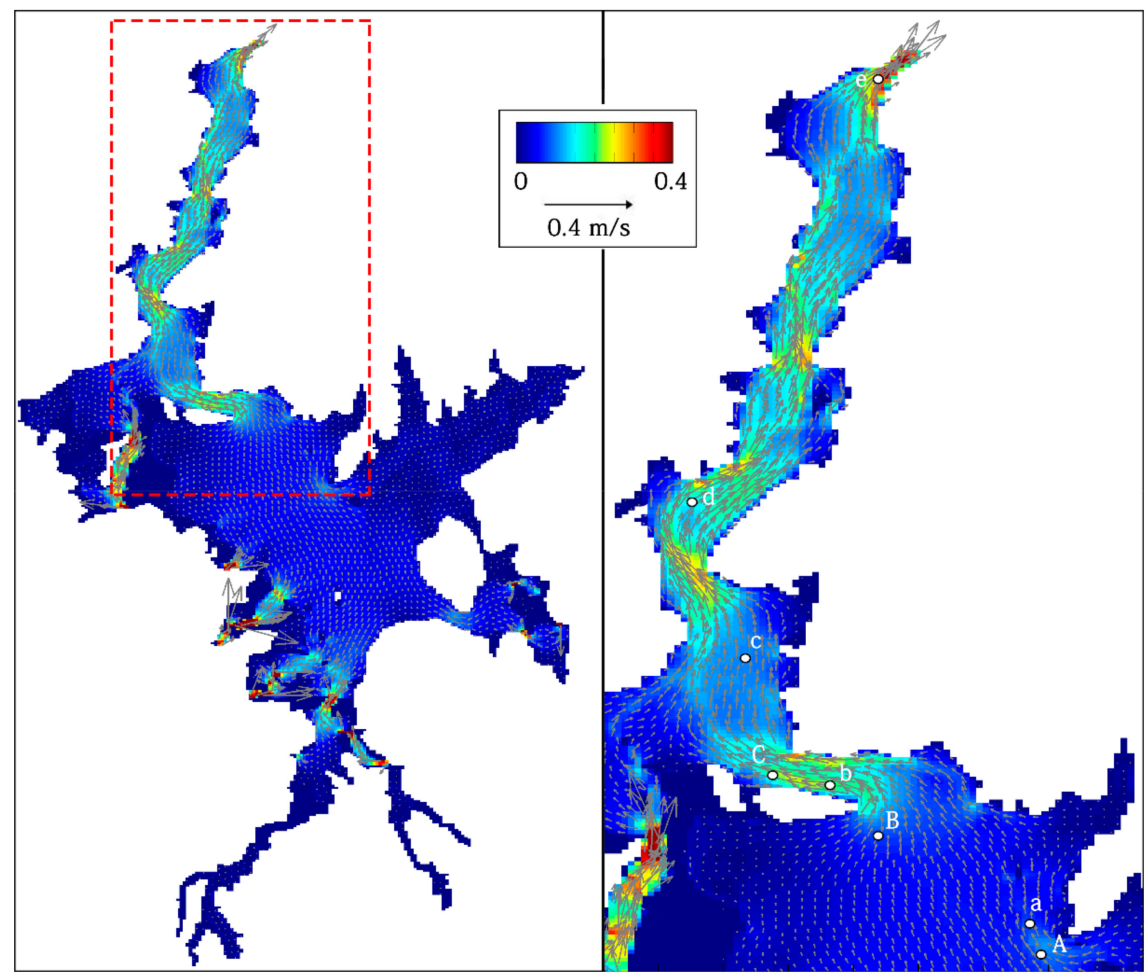

Figure 12. The simulated velocity field in the north of Poyang Lake. 
The recovery time to normal status for Huamiao lakelet, together with the simulated velocity field, is shown in Figure 13. The recovery time to normal status exceeded 18 days and was longer in the northern lakelet. According to the velocity field that was simulated, the water flow rate was much slower here, and the velocity was lower than $0.1 \mathrm{~m} / \mathrm{s}$ for most of the grid cells, decreased gradually from open water to the lakeshore, forming a closed annular flow field separated in the bay. This means a low exchange rate for water flow, and also a low diffusion rate for the SSC, resulting from sand dredging activities.
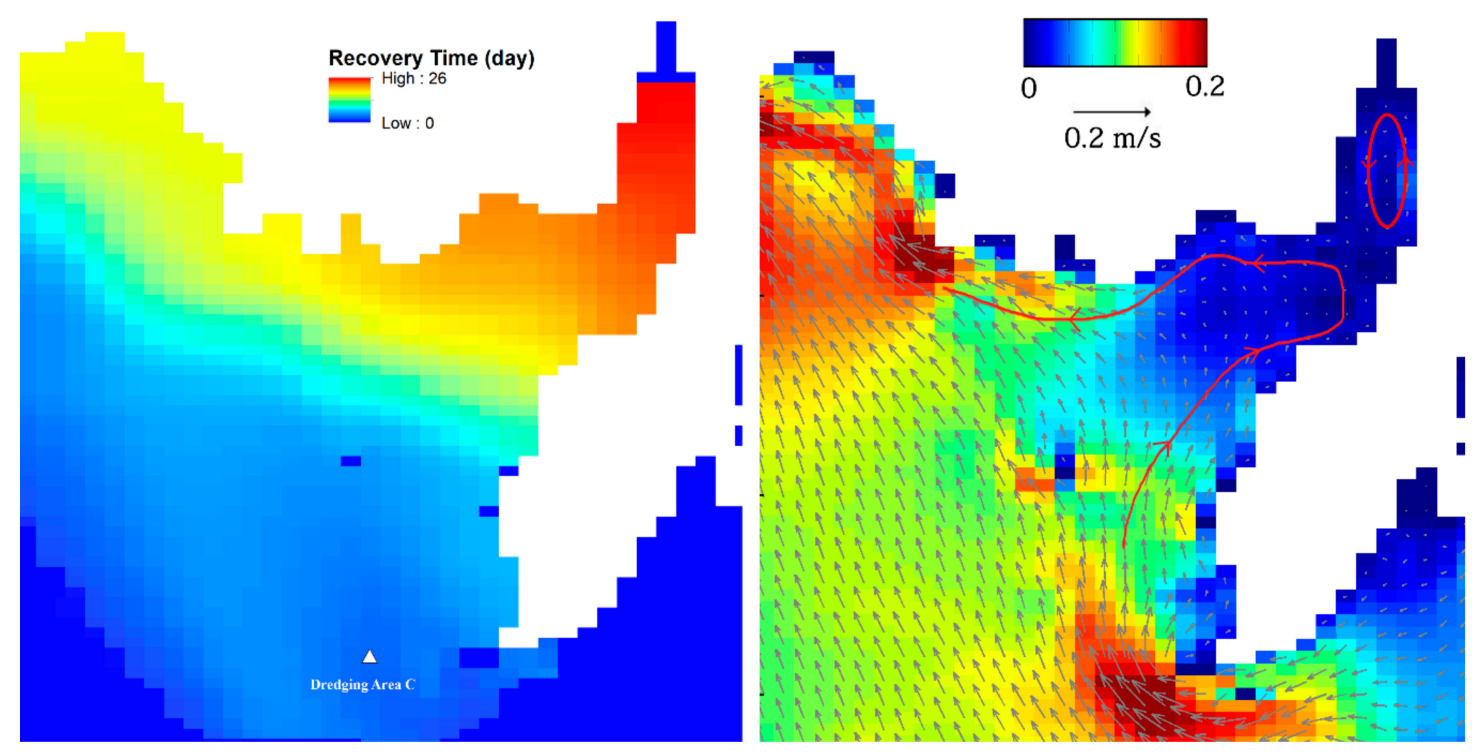

Figure 13. The recovery time to normal status and corresponding velocity field in the Huamiao lakelet, southeastern Poyang Lake.

As with the recovery time for the SSC to normal status after sand dredging stopped, the water age could be used to describe the characteristics for the water residence and transport process. Li et al. indicated a lower exchange rate and a longer time for water residence with a greater water age, and vice versa [42]. Qi et al. simulated the spatial and temporal distribution pattern of the water age of Poyang Lake based on a hydrodynamic model named EFDC in 2011 [43]. It showed that it is difficult for the suspended sediment to diffuse in an area with a higher water age. Compared with the distribution of the water age in the Huamiao lakelet, the time to recover to normal status for the SSC after sand dredging stopped varied from short to long from the open water to the lakeshore. Additionally, the water age of the northern lake presented an increasing trend, which was in good agreement with the spatial pattern of the recovery time for the SSC in the north of the lake.

\section{Conclusions}

The main purpose of this study was to reveal the characteristics of hydrodynamic variations and their impacts on the SSC, caused by sand dredging activities at the spatial and temporal scale, in Poyang Lake, the largest freshwater lake with high turbidity in China. With the help of remote sensing technology and numerical simulation, a sediment transport method integrated with sand dredging was built for the Poyang Lake, considering the sand dredging activities. The hydrodynamic process was well validated against observed data and remote sensing results, showing the dramatic changes of the inundation area in the dry and wet seasons annually and inter-annually. Both the numerical model and remote sensing have the capability to observe the high-dynamic changes in the hydrologic regime of the lake.

Integrated with the validated hydrodynamic model, the two-dimensional sediment transport model was employed with consideration of sand dredging activities detected from Landsat images. Based on the observed data and remote sensing results, the sand dredging areas were determined to 
set up scenario simulations. This is a feasible way to monitor dredging activities with a moderate resolution. The simulation of the SSC, which indicated close agreement with the MODIS derived results, could be more effective by considering the dredging activities in Poyang Lake. Further explorations of spatiotemporal variations of the SSC were conducted with the help of corresponding scenario simulations designed under different dredging intensities. The three main dredging areas showed nearly no effects on the SSC in the southern main lake, but notable effects in downstream areas in the north of the lake, with a total affected area of $730 \mathrm{~km}^{2}$.

The dredging activities were one of the main factors causing high turbidity in the north of Poyang Lake. The proposed suspended sediment transport model integrated with sand dredging was proven to effectively simulate the influence of dredging activities quantitatively, which improved the model accuracy for human induced high turbidity. However, because of difficulty quantifying sediment release from the pump during sand dredging, the dredging intensities were approximately estimated by the number of dredging vessels, and then integrated with the sediment transport model with scenario simulations of different intensities in this study. In fact, this study demonstrated that the proposed method enables us to evaluate the impacts of dredging activities on the suspended sediment pattern at the spatial and temporal scale. In the case that the monitoring instrument is equipped on the dredging pump, the real time sediment release into the water could be observed as a point source of sediment integrated into the model. This study provided an analysis tool to understand water quality under an intensive impact of human activities for water resource management.

Author Contributions: Conceptualization, J.L. and X.C.; methodology and validation, H.L.; write, J.L. and H.L.; review and editing, D.L.; Project administration and funding acquisition, J.L.

Funding: This work was funded by the Frontier Project of Applied Foundation of Wuhan (2019020701011502), the Natural Science Foundation of Hubei Province (2019CFB736), the Fundamental Research Funds for the Central Universities (2042018kf0220), the open foundation of Jiangxi Engineering Research Center of Water Engineering Safety and Resources Efficient Utilization (OF201601), and the LIESMARS Special Research Funding.

Acknowledgments: We would also thank the Delft Hydro-Morphodynamics for providing open source code of Delft3D-Flow.

Conflicts of Interest: The authors declare no conflict of interest.

\section{References}

1. Vos, R.J.; Brummelhuis, P.G.J.T.; Gerritsen, H. Integrated data-modelling approach for suspended sediment transport on a regional scale. Coast. Eng. 2000, 41, 177-200. [CrossRef]

2. Miller, R.L.; Castillo, C.E.D.; Chilmakuri, C.; Mccorquodale, J.A. Using MULTI-temporal MODIS $250 \mathrm{~m}$ Data to Calibrate and Validate a Sediment Transport Model for Environmental Monitoring of Coastal Waters. In Proceedings of the IEEE International Workshop on the Analysis of Multi-Temporal Remote Sensing Images, Biloxi, MS, USA, 16-18 May 2005; Volume 62, pp. 200-204. [CrossRef]

3. Kunte, P.D.; Zhao, C.; Osawa, T.; Sugimori, Y. Sediment distribution study in the Gulf of Kachchh, India, from 3D hydrodynamic model simulation and satellite data. J. Mar. Syst. 2005, 55, 139-153. [CrossRef]

4. Elias, E.P.L.; Cleveringa, J.; Buijsman, M.C.; Roelvink, J.A.; Sive, M.J.F. Field and model data analysis of sand transport patterns in Texel Tidal inlet (The Netherlands). Coast. Eng. 2006, 53, 505-529. [CrossRef]

5. Fettweis, M.; Nechad, B.; Van den Eynde, D. An estimate of the suspended particulate matter (SPM) transport in the southern North Sea using SeaWiFS images, in situ measurements and numerical model results. Cont. Shelf Res. 2007, 27, 1568-1583. [CrossRef]

6. Chen, X.; Lu, J.; Cui, T.; Jiang, W.; Tian, L.; Chen, L.; Zhao, W. Coupling remote sensing retrieval with numerical simulation for SPM study-Taking Bohai Sea in China as a case. Int. J. Appl. Earth Obs. Geoinform. 2010, 12, 203-211. [CrossRef]

7. Liang, D.; Lu, D.; Chen, X.; Zhang, L. Numerical simulation of hydrological and hydrodynamic responses to channel erosion in China's largest freshwater lake. Appl. Ecol. Environ. Res. 2019, 17, 6865-6886. [CrossRef]

8. Hossain, S.; Eyre, B.D.; McKee, L.J. Impacts of dredging on dry season suspended sediment concentration in the Brisbane River Estuary, Queensland, Australia. Estuar. Coast. Shelf S. 2004, 61, 539-545. [CrossRef] 
9. Thibodeaux, L.; Duckworth, K. The Effectiveness of Environmental Dredging: A Study of Three Sites. Remediation 2001, 11, 5-33. [CrossRef]

10. Alam, S.; Matin, M.A. Application of 2D morphological model to assess the response of Karnatuli River due to capital dredging. J. Water Resour. Ocean. Sci. 2013, 2, 40-48. [CrossRef]

11. Jeroen, S. The Influence of Dredging Activities on the Morphological Development of the Columbia River Mouth. MSc Thesis, Department of Hydraulic Engineering Section of Coastal Engineering, Delft University of Technology, TU Delft, Delft, The Netherlands, 2012.

12. Cheng, X.; Wan, Y.; Cao, B. Identification of sand dredges in Yangtze River based on ASAR remote sensing data. In Proceedings of the 17th International Conference on Geoinformatics, IEEE, Fairfax, VA, USA, 12-14 August 2009; pp. 1-5. [CrossRef]

13. Evans, R.D.; Murray, K.L.; Field, S.N.; Moore, J.A.; Shedrawi, G.; Huntley, B.G.; Fearms, P.; Broomhall, M.; Mckinna, L.I.; Marrable, D. Digitise this! A quick and easy remote sensing method to monitor the daily extent of dredge plumes. PLoS ONE 2012, 7, 16733-16737. [CrossRef]

14. He, M.X.; Hu, L.; Hu, C. Harbour dredging and fish mortality in an aquaculture zone: Assessment of changes in suspended particulate matter using multi-sensor remote-sensing data. Int. J. Remote Sens. 2014, 35, 4383-4398. [CrossRef]

15. Islam, M.A.; Wang, L.; Smith, C.; Reddy, R.; Lewis, A.; Smith, A. Evaluation of satellite remote sensing for operational monitoring of sediment plumes produced by dredging at Hay Point, Queensland, Australia. J. Appl. Remote Sens. 2007, 1, 011506. [CrossRef]

16. Sipelgas, L.; Raudsepp, U. Monitoring of HARBOR dredging Using Remote Sensing and Optical In Situ Data. In Proceedings of the IEEE International Geoscience and Remote Sensing Symposium, Cape Town, South Africa, 12-17 August 2009; pp. II-476-II-478. [CrossRef]

17. Lu, J.; Chen, X.; Zhang, P.; Huang, J. Evaluation of spatiotemporal differences in suspended sediment concentration derived from remote sensing and numerical simulation for coastal waters. J. Coast. Conserv. 2017, 21, 197-207. [CrossRef]

18. Jordan, Y.C.; Ghulam, A.; Hartling, S. Traits of surface water pollution under climate and land use changes: A remote sensing and hydrological modeling approach. Earth-Sci. Rev. 2014, 128, 181-195. [CrossRef]

19. Milzow, C.; Kgotlhang, L.; Kinzelbach, W.; Meier, P.; Bauer-Gottein, P. The role of remote sensing in hydrological modelling of the Okavango Delta, Botswana. J. Environ. Manag. 2009, 90, 2252-2260. [CrossRef]

20. Oey, L.-Y.; Ezer, T.; Hu, C.; Muller-Karger, F.E. Baroclinic tidal flows and inundation processes in Cook Inlet, Alaska: Numerical modeling and satellite observations. Ocean. Dynam. 2007, 57, 205-221. [CrossRef]

21. Van Dongeren, A.; Plant, N.; Cohen, A.; Roelvink, D.; Haller, M.C.; Catalan, P. Beach Wizard: Nearshore bathymetry estimation through assimilation of model computations and remote observations. Coast. Eng. 2008, 55, 1016-1027. [CrossRef]

22. Feng, L.; Hu, C.; Chen, X.; Cai, X.; Tian, L.; Gan, W. Assessment of inundation changes of Poyang Lake using MODIS observations between 2000 and 2010. Remote Sens. Environ. 2012, 121, 80-92. [CrossRef]

23. Wu, G.; Cui, L. Remote sense-based analysis of sand dredging impact on water clarity in Poyang Lake. Acta Ecol. Sin. 2008, 28, 6113-6120. (in Chinese).

24. Cui, L.; Qiu, Y.; Fei, T.; Wu, G. Using remotely sensed suspended sediment concentration variation to improve management of Poyang Lake, China. Lake Reserv. Manag. 2013, 29, 47-60. [CrossRef]

25. Lai, X.; Shankman, D.; Huber, C.; Yeou, H.; Huang, Q.; Jiang, J. Sand mining and increasing Poyang Lake's discharge ability: A reassessment of causes for lake decline in China. J. Hydrol. 2014, 519, 1698-1706. [CrossRef]

26. Li, J.; Tian, L.; Chen, X.; Li, X.; Lu, J.; Feng, L. Remote-sensing monitoring for spatio-temporal dynamics of sand dredging activities at Poyang Lake in China. Int. J. Remote Sens. 2014, 35, 6004-6022. [CrossRef]

27. Chen, X.; Wu, Z.; Tian, L.; Chen, L. Inversion model for dynamic monitoring of suspended sediment: A case study on Poyang Lake. Sci. Technol. Rev. 2007, 25, 19-22. [CrossRef]

28. Wu, G.; Cui, L.; Duan, H.; Fei, T.; Liu, Y. An approach for developing Landsat-5 TM-based retrieval models of suspended particulate matter concentration with the assistance of MODIS. ISPRS J. Photogramm. 2013, 85, 84-92. [CrossRef]

29. Wu, G.; Cui, L.; He, J.; Duan, H.; Fei, T.; Liu, Y. Comparison of MODIS-based models for retrieving suspended particulate matter concentrations in Poyang Lake, China. Int. J. Appl. Earth Obs. 2013, 24, 63-72. [CrossRef] 
30. Zhang, P.; Wai, O.W.H.; Chen, X.; Lu, J.; Tian, L. Improving Sediment Transport Prediction by Assimilating Satellite Images in a Tidal Bay Model of Hong Kong. Water 2014, 6, 642-660. [CrossRef]

31. Leeuw, J.; Shankman, D.; Wu, G.; de Boer, W.F.; Burnham, J.; He, Q.; Yesou, H.; Xiao, J. Strategic assessment of the magnitude and impacts of sand mining in Poyang Lake, China. Reg. Environ. Chang. 2009, 10, 95-102. [CrossRef]

32. Zhang, P.; Lu, J.; Feng, L.; Chen, X.; Zhang, L.; Xiao, X.; Liu, H. Hydrodynamic and Inundataion modeling of China's Largest Freshwater Lake aided by remote sensing data. Remote Sens. 2015, 7, 4858-4879. [CrossRef]

33. Feng, L.; Hu, C.; Chen, X.; Tian, L.; Chen, L. Human induced turbidity changes in Poyang Lake between 2000 and 2010: Observations from MODIS. J. Geophys. Res.-Oceans 2012, 117. [CrossRef]

34. Gao, J.; Jia, J.; Kettner, A.J.; Xing, F.; Wang, Y.; Xu, X.; Yang, Y.; Zou, X.; Gao, S.; Qi, S.; et al. Changes in water and sediment exchange between the Yangtze River and Poyang Lake under natural and anthropogenic conditions, China. Sci. Total Environ. 2014, 481, 542-553. [CrossRef]

35. Huete, A.; Didan, K.; Miura, T.; Rodriguez, E.P.; Gao, X.; Ferreira, L.G. Overview of the radiometric and biophysical performance of the MODIS vegetation indices. Remote Sens. Environ. 2002, 83, 195-213. [CrossRef]

36. Delft Hydraulics. Delft3d-Flow User Manual: Simulation of Multi-Dimensional Hydrodynamic Flows and Transport Phenomena, Including Sediments; Deltares: Delft, The Netherlands, 2014; pp. 1-683.

37. Lesser, G.; Roelvink, J.; van Kester, J.; Stelling, G. Development and validation of a three-dimensional morphological model. Coast. Eng. 2004, 51, 883-915. [CrossRef]

38. Zhang, P.; Chen, X.; Lu, J.; Zhang, W. Assimilation of remote sensing observations into a sediment transport model of China's largest freshwater lake: Spatial and temporal effects. Environ. Sci. Pollut. Res. 2015, 22, 18779-18792. [CrossRef] [PubMed]

39. Tang, L.; Xiao, Y.; Zhou, H.; Luo, J.; Tang, H. Research on the effect factors of flow diversion ratio in Ganjiang River. Hydro-Sci. Eng. 2011, 27, 64-68. [CrossRef]

40. Zhang, P.; Chen, X.; Lu, J.; Zhang, W.; Xiao, X. Suspended sediment transport modeling of Poyang Lake in the wet season based on remote sensing data. Geomat. Inform. Sci. Wuhan Univ. 2017, 42, 369-376. [CrossRef]

41. Pennekamp, J.G.S.; Epskamp, R.J.C.; Rosenbrand, W.F.; Mullie, A.; Wessel, G.L.; Arts, T.; Deibel, I.K. Turbidity caused by dredging: Viewed in perspective. Terra Aqua 1996, 64, 10-17.

42. Li, Y.; Acharya, K.; Chen, D.; Stone, M. Modeling water ages and thermal structure of Lake Mead under changing water levels. Lake Reserv. Manag. 2010, 26, 258-272. [CrossRef]

43. Qi, H.; Lu, J.; Chen, X.; Sauvage, S.; Sanchez-Perez, J.-M. Water age prediction and its potential impacts on water quality using a hydrodynamic model for Poyang Lake, China. Environ. Sci. Pollut. Res. 2016, 23, 13327-13341. [CrossRef]

(C) 2019 by the authors. Licensee MDPI, Basel, Switzerland. This article is an open access article distributed under the terms and conditions of the Creative Commons Attribution (CC BY) license (http://creativecommons.org/licenses/by/4.0/). 